\title{
WOMEN IN THE CRUSADER STATES: THE QUEENS OF JERUSALEM (I IOO-II9O)
}

by BERNARD HAMILTON

7 HE important part played by women in the history of the crusader states has been obscured by their exclusion from the 1 battle-field. Since scarcely a year passed in the Frankish east which was free from some major military campaign it is natural that the interest of historians should have centred on the men responsible for the defence of the kingdom. Yet in any society at war considerable power has to be delegated to women while their menfolk are on active service, and the crusader states were no exception to this general rule. Moreover, because the survival rate among girl-children born to Frankish settlers was higher than that among boys, women often provided continuity to the society of Outremer, by inheriting their fathers' fiefs and transmitting them to husbands many of whom came from the west.

The queens of Jerusalem are the best documented group of women in the Frankish east and form an obvious starting-point for any study of the role of women there. There is abundant evidence for most of them in a wide range of sources, comprising not only crusader chronicles and documents, but also western, Byzantine, Syriac and Armenian writers. Arab sources very seldom mentioned them: the moslem world was clearly shocked by the degree of social freedom which western women enjoyed ${ }^{1}$ and reacted to women with political power much as misogynist dons did to the first generation of women undergraduates, by affecting not to notice them. Despite the fulness of the evidence there is, so far as I am aware, no detailed study of any of the twelfth century queens of Jerusalem with the notable exception of Mayer's article on Melisende. ${ }^{2}$ For reasons of brevity only the queens of the first kingdom will be considered here.

Godfrey of Bouillon, the first Frankish ruler, was a bachelor and no woman occupied a central position in the state until his brother,

1 The Autobiography of Ousâma, trans G. R. Potter, (London 1929) p 177.

2 [H. E.] Mayer, ['Studies in the History of Queen Melisende of Jerusalem',] DOP 26 (1972) PP 93-183. 


\section{BERNARD HAMILTON}

Baldwin I, count of Edessa, succeeded him in I 1oo. Baldwin's wife, Godvera, had accompanied him on crusade, but had died at Marasch in October $10977^{3}$ Soon after this Baldwin married the daughter of the Armenian prince Thoros, brother of Constantine the Roupenian. Paoli called her Arda, and it is convenient to use this name, although it is given in no source known to me. She was an only child, and potentially a great heiress ${ }^{5}$ and was promised a dowry of 60,000 bezants which her impoverished husband sorely needed to raise troops to defend his county, while he also benefitted from the advice and alliance of his father-in-law. ${ }^{6}$

When he was summoned to Jerusalem in I I0o Baldwin travelled there by the hazardous land-route, but his wife and her ladies waited at Antioch for a ship to take them south. ${ }^{7}$ Possibly the queen did not make the journey that winter: she would have needed a strong naval escort, since most of the coastal cities were still held by the moslems. Certainly she does not seem to have been present at Bethlehem when Baldwin was crowned there on Christmas day. By IIOI Arda had reached Jaffa, possibly escorted by a Genoese fleet which had wintered at Laodicea. ${ }^{8}$ When the battle of Ramleh was fought in September I IoI she was still at Jaffa, and when a false rumour reached the garrison that the king had been killed she took charge and sent a message by sea to Antioch asking Tancred for help. ${ }^{9}$

Nothing more is known about her until the king repudiated her. William of Tyre implies that this happened before I IOS, but Guibert of Nogent, a contemporary source, places it more exactly immediately after Arda's arrival in the kingdom. He tells a romantic story of how the king put away his wife because she had been raped by pirates on the

- A[lbert of] A[ix, Historia Hierosolymitana,] bk 3, cap 27, RHC Occ 4, P 358; H. Hagenmeyer, Chronologie de la première Croisade (1094-1100) (Paris 1902) no 196, pp 101-2. compare Orderic [Vitalis, Historia Ecclesiastica,] bk S, cap 13, ed A. Le Prévost, L. Delisle, 5 vols (Paris 1838-55) 2, p 404.

- C. [du Fresne] Du Cange, [Les Familles d'Outremer, ed E. G. Rey] (Paris I869) p Ix.

- W. H. Ridit-Collenberg, The Rupenides, Hethumides and Lusignans. The Structure of the Armeno-Cilician Dynasties, Calouste Gulbenkian Foundation Armenian Library (Paris 1963) table $I$ and $P$ so no 7.

- AA bk 3, cap 31, RHC Occ 4, P 36I places the marriage before Baldwin reached Edessa in March ro98; W[illiam of] T[yre, Historia rerum in partibus transmarinis gestarum,] bk 10, cap I, RHC OCc I, p 402 places it after he came to Edessa.

2 WT bk ro, cap 5, RHC Occ 1, p 407; Guibert [of Nogent, Gesta Dei per Francos,] bk 7, cap 48, RHC Oce 4, p 259.

- F[ulcher of] C[hartres, Historia Hierosolymitana (1095-1127),] bk 2, cap 8, [ed H. Hagenmeyer] (Heidelberg 1913) pp 393-4.

- Ibid bk 2, cap 14, P 42I. 


\section{Queens of Jerusalem}

voyage south. ${ }^{10}$ William of Tyre is more cautious: some people, he says, believed that the queen had been unfaithful, but others supposed that the king wished to make a more advantageous marriage. Fulcher of Chartres who, as Baldwin's chaplain, was in a unique position to know the truth about the separation, is totally silent. This suggests that the rumours about the queen's unfaithfulness were not true, since if they had been the king's repudiation of his wife would have met with general sympathy. Fulcher's silence implies that the king's action was criticised, and circumstantial evidence suggests that Baldwin's motives were political rather than moral: the marriage to a Roupenian princess which had been politically advantageous to him as count of Edessa was valueless to him as king of Jerusalem; the bride's father had only paid a fraction of the dowry; ${ }^{11}$ and the queen was still childless after several years of marriage. ${ }^{12}$ All these factors suggest that Baldwin's chief concern was to marry a richer wife who would bear him an heir. The marriage was not annulled. William of Tyre states that the separation took place 'without due process of law', and the queen was forced to take the veil at Saint Anne's Jerusalem. ${ }^{13}$ She lived as a nun for some years and then asked permission to visit her kin in Constantinople on a fund-raising mission. Once there she abandoned the religious habit and, according to William of Tyre, lived promiscuously, ${ }^{14}$ though this may be doubted since the king later professed his readiness to take her back.

A suitably rich replacement for Arda was not immediately available, and Jerusalem was without a queen for some years. Then in I I 2 the patriarch Arnulf persuaded Baldwin to seek the hand of Adelaide, countess dowager of Sicily, who must have been in her late thirties. ${ }^{15}$ Since the death of her husband, Roger I, in IIOI, she had acted as regent of Sicily until Roger II came of age in $1112 .{ }^{16}$ An alliance with

${ }^{10}$ Guibert, bk 7, cap 48, RHCOce 4, p 259.

117,000 of the promised 60,000 bezants, AA bk 3, cap 31. RHC Occ 4, p 361 .

12 Orderic bk 9, cap I1, 3, p 570 .

12 Although this was later a Latin convent it may have been an eastern rite community at this time, since Arda was an Armenian Christian. B. Hamilton, 'Rebuilding Zion: the Holy Places of Jerusalem in the twelfth century', SCH 14 (1977) p 111.

14 WT bk II, cap I, RHC Occ I, pp 45I-2.

13 She married Roger I in 1089 as a young woman and had probably been born in cro74. Her marriage settlement shows that she was not considered to be above the age of child-bearing in 1113 and there seems no reason for crediting Orderic Vitalis's report that she was a wrinkled old hag when she married Baldwin, Orderic bk 13 , cap Is, S. P 36.

10 For an account of her regency see J. J. Norwich, The Normans in the South (London 1967) pp 280-9. 
Sicily, the nearest western power to the crusader states, and one which had a strong navy, was attractive to Baldwin, and so was the countess's wealth, of which his penurious kingdom stood in great need. $\mathrm{He}$ therefore instructed his envoys to agree to any conditions which the Sicilian court might make: these were onerous, for it was required that not only should any child born of the marriage be heir to the kingdom, but also that if the union were childless Roger II of Sicily should succeed Baldwin. The countess reached Acre in August III 3 with a large dowry ${ }^{17}$ and also, according to Albert of Aix, with a thousand men-at-arms in her suite and a company of Saracen archers. It is a matter of conjecture whether her ship-of-state was so ornate as Albert reports, since he was writing from hearsay. ${ }^{18}$

Initially the countess's money eased the financial problems of the state, but she failed to produce the heir that the king needed. ${ }^{19}$ The prospect of the succession of the count of Sicily, which became more likely as the countess passed the age of childbearing, was not viewed with enthusiasm by some of the Jerusalem baronage. They attacked the marriage-settlement indirectly through the patriarch. Arnulf was very vulnerable: he was accused of simony and concubinage, and was also denounced for solemnising a bigamous marriage between Baldwin and Adelaide while the king's first wife was still alive at Constantinople. The case finally went to Rome where, as his opponents had perhaps correctly calculated, Arnulf was able to clear himself of all the charges made against him except that relating to the Sicilian marriage where the facts were beyond dispute. In July i I 6 Paschal II re-instated him as patriarch ${ }^{20}$ on condition that he secured the separation of Baldwin and Adelaide. ${ }^{21}$ That proved easy, because in the winter of that year Baldwin fell gravely ill and was persuaded by his clergy that he had contracted a bigamous marriage. He therefore vowed to dismiss Adelaide and recall Arda, a decision which seems to have been motivated solely by religious conviction, since he would have gained nothing from a reconciliation with his long-estranged wife. ${ }^{22}$

Life in the royal household must have been strained in the Lent of

17 WT bk II, cap 2I, RHC Occ I, pp 487-9; FC bk 2, cap 51, PP 575-7 relates her arrival but says nothing about her dowry.

${ }^{18}$ AA bk 12, cap 13, RHC Occ 4, pp 696-7.

19 WT bk 11, cap 2I, RHC Oce I, p 489.

${ }^{20} \mathrm{FC}$ bk 2, cap 54, p 591; WT bk II, cap 26, RHC Occ I, p 499; Paschal II's bull of 19 July 1116 in [E.] de Rozière, [Cartulaire de l'Église du Saint-Sépulchre de Jérusalem], Collection des documents inédits sur l'histoire de France, 1 ser, 5 (Paris I 849) no I 1, PP I I-1 3.

"AA bk 12, cap 24, RHC Occ 4, p 704.

2FC bk 2, cap 59, p 601; WT bk II, cap 29, RHC Occ I, P 506. 


\section{Queens of Jerusalem}

II17. The queen was highly indignant at the treatment she had received, and had to undergo the further humiliation of having her marriage annulled by a church synod at Acre. ${ }^{23}$ Moreover, though she lost her husband and her royal status she did not recover her dowry, which had been spent. On Saint Mark's day I I 17 she finally sailed to Sicily, ${ }^{24}$ vowing to build churches to Saint Anne and the Blessed Virgin if she made the journey in safety. She fulfilled this vow, ${ }^{25}$ but she did not long enjoy the peace of Sicily, where she died on I6 April II $8 .{ }^{26}$ The ill-treatment accorded to her was not only inhumane, it was also politically ill-advised. Her son never forgave the insult to his mother or the disregard of his own rights of succession under the terms of her marriage settlement. Writing some fifty years later William of Tyre laments that the rulers of Sicily, alone of all the kings of the West, had never sent help to Jerusalem. ${ }^{27}$

Queen Arda did not return to her husband after Adelaide's departure, and when Baldwin I died in 1 I 8 there was no queen in Jerusalem. He was succeeded by his cousin, Baldwin II, count of Edessa, who had come to Jerusalem on pilgrimage and arrived there by chance in time for his predecessor's funeral. ${ }^{28}$ Baldwin II had also married an Armenian wife after he became count of Edessa, probably in II00. She was Morphia, daughter of Gabriel of Melitene who, though an Armenian, was Orthodox in religion. The alliance of Gabriel was initially valuable to Baldwin, as, no doubt, was the large dowry which his wife brought him. ${ }^{29}$ Unlike his royal cousin, Baldwin II was happily married; it was as well for Morphia that this was so, since she signally failed to meet two of the chief requirements in the wife of any medieval ruler: her father's principality was conquered by the Turks soon after her marriage, so that no long-term political advantage accrued to her husband from the match; and she failed to produce a male heir. When Baldwin became king the couple had three daughters, Melisende, Alice and Hodierna, and the queen subsequently gave birth to a fourth girl,

\footnotetext{
23 AA bk 12, cap 24, RHC Occ 4, P 704.

24 FC bk 2, cap 60, p 602.

${ }^{25}$ [H. F.] Delaborde, [Chartes de la Terre Sainte provenant de l'abbaye de Notre-Dame de Josaphat,] B[ibliothèque des] E[coles] F[rançaises d'] $A$ [thènes et de] R[ome], 19 (Paris 1880 ) no 20, pp 38-40.

${ }^{26} \mathrm{FC}$ bk 2, cap 63, p 608 and $\mathrm{n} 14$.

27 WT bk 12, cap 29, RHC Occ I, p so6.

${ }^{28}$ Ibid bk 12, cap 2, RHC Occ 1, pp S12-13; FC bk 3, cap I, p 616.

20 WT bk Io, cap 24, RHC OCe I, p 437, places this marriage before the arrival of Jocelyn Courtenay in the east with the crusade of 1101 .
} 
Yveta. ${ }^{30}$ Matthew of Edessa remarks that Baldwin was devoted to his wife ${ }^{31}$ and this is borne out by the fact that he delayed his coronation for almost eighteen months, until Christmas day I I I9, so that she could travel to Jersualem and be crowned with him. ${ }^{32}$

Perhaps as a result of the oriental environment in which she had grown up the queen took no part in the public life of the kingdom: her name is never associated with Baldwin's in any of his acts. Nevertheless, she was capable of taking the initiative in political affairs when necessary. When the king was captured by Nur-ad-Dualah Balak in 1123 Morphia is alleged to have hired Armenians who disguised themselves as Turks and infiltrated the garrison of Kharpart where the king was held. ${ }^{33}$ She certainly took a central part in the negotiations leading to Baldwin's release in II24, travelling to north Syria, and handing over her youngest daughter, Yveta, as a hostage to stand surety for the payment of the king's ransom. ${ }^{34}$ Paradoxically, although the exact day of Morphia's death is known-it was I October- ${ }^{35}$ the year is not, although it took place before I I29. She was buried in the shrine church of our Lady of Josaphat at Jerusalem. ${ }^{36}$

Neither Morphia nor either of the wives of Baldwin I had taken any public part in the government of the kingdom, but because Baldwin II had no sons he recognised his eldest daughter, Melisende, as his heir, and towards the end of his reign she began to be associated with him in official documents. In March I 129 she witnessed a grant which the king made to the Holy Sepulchre and took precedence over all the clergy, ${ }^{37}$ while in another document from about the same period she

so Ibid bk I2, cap 4, RHC Occ I, P 517.

s1 M[atthew of] E[dessa, Chronique d'Arménie,] cap 76, Armenian text with French translation, $R H C$ Arm I, p I I9.

${ }^{22} \mathrm{FC} \mathrm{bk} \mathrm{3,} \mathrm{cap} \mathrm{7,} \mathrm{p} 635$.

30 Armenian infiltrators certainly played some part in Baldwin's escape attempt. WT bk I 2, cap 18, RHC Occ I, pp 538-9; Morphia's involvement is recorded by Orderic, bk II, cap 26, 4, pp 2so-I.

3 ME cap 91, RHC Arm I, p I39.

${ }^{85}$ Entry in the calendar of queen Melisande's psalter, ed [H.] Buchtal, [Miniature Painting in the Latin Kingdom of Jerusalem] with liturgical and palaeographical chapters by F. Wormald (Oxford 1957) pp 124-6.

so [C.] Kohler, ['Chartes de l'abbaye de Notre-Dame de la vallée de Josaphat en Terre Sainte (1 108-129I). Analyse et extraits'], R[evue de l'] O[rient] L[atin], 7 (Paris I899) no 21, p I 28, which was drawn up before Melisende's marriage in June 1129 . Compare de Rozière no 46, pp $85-6$, in which Baldwin II remits some customs charges on pilgrims in the port of Acre for the repose of Morphia's soul.

37 de Rozière no 44, pp 8I-3. This is dated the fourth indiction, March II28. The indiction has certainly been wrongly transcribed. As the patriarch Stephen was present on this occasion, and only took office in 1128 , it seems likely that the new year 


\section{Queens of Jerusalem}

styled herself filia regis et regni Jerosolimitani haeres. ${ }^{38}$ She married count Fulk V of Anjou, an experienced ruler, and a widower with grown sons who had been chosen as her husband by Louis VI of France. The wedding took place at whitsuntide 1 1 29. Mayer argues that Baldwin II had originally promised Fulk sole right of succession, implying that Melisende was only to be queen-consort, but that on his deathbed he altered the terms of the settlement and associated Melisende and the infant Baldwin III with Fulk as joint-heirs, fearing lest after his death Fulk should repudiate Melisende and make one of the sons of his first marriage his heir. This is not convincing, since the accounts which William of Tyre gives of the terms of the marriage settlement and of the king's dying wishes are not incompatible: in the account of the marriage settlement there is nothing to suggest that Baldwin was intending to exclude Melisende from power. An important indication of Baldwin's intentions in the matter of the succession is the grant which he made to the Holy Sepulchre in I I 30-I, in which he associated both Fulk and Melisende with him, which implies that from the time of the marriage he treated them as joint-heirs of the kingdom..$^{39}$ In I 30 Melisende gave birth to the future Baldwin III, and thus the succession was assured before the death of her father on 2 I August I 3 I. On Holy Cross Day, I4 September, an important feast in the crusader kingdom, Fulk and Melisende were crowned in the church of the Holy Sepulchre. ${ }^{40}$

After her father's death Melisende did not enjoy the power which she had previously possessed: she is not associated with Fulk in any public act in the first five years of his reign. The revolt of Hugh II of Le Puiset, count of Jaffa, which Mayer convincingly argues took place in I 134, happened in this period. The facts of this cause célebre are known only through William of Tyre. The king took a strong dislike to Hugh who was thought to be having a liaison with the queen. Some time later Hugh's stepson accused him of treason in the curia regis, and Hugh retired to Jaffa, allied with the moslems of Ascalon and defied the royal army which was sent against him. Peace was mediated by the patriarch, who obtained lenient terms from the king: the rebels were to be exiled

reckoning employed began on March 25 and that in modern style the document should be dated March I 129.

${ }^{38}$ Kohler, $R O L$ 7, no $2 \mathrm{I}, \mathrm{p} 128$.

${ }^{39}$ de Rozière no 43, pp 80-I. The marriage settlentent is in WT bk 13 , cap 24, RHC Occ

1, P 594: the account of the dying king's wishes ibid bk 13, cap 28, RHC Occ I PP 601-2. See Mayer, DOP 26, pp 99-102.

10 WT bk 14, cap 2, RHC Occ 1, pp 608-9. 


\section{BERNARD HAMILTON}

for three years, but at the end of that time they might return and resume their fiefs. But before Hugh left, an unsuccessful assassination attempt was made on him, which was commonly supposed to have been instigated by the king, although his collusion was never proved. Hugh then went to Apulia, where he died before his sentence had run its term, but the queen bitterly resented the way Hugh had been treated and the slight on her own honour. As a result, the king's supporters went in terror of their lives, and even the king himself did not feel safe among the queen's suite. Finally peace was mediated between Fulk and Melisende and, concludes William of Tyre, the king 'did not attempt to take the initiative, even in trivial matters, without her knowledge'. ${ }^{11}$

Mayer is undoubtedly correct in discounting the love element in this story: if Fulk had been a wronged husband a strong section of public opinion, led by the church, would have sided witl him, not, as it did, with the queen, in a matter which might concern the royal succession. Mayer rightly sees the conflict as a dispute between the king's supporters, and those whose loyalties lay with the queen as Baldwin II's daughter. Hugh of Le Puiset, who was Melisende's second cousin, and the only great nobleman of the blood royal in the kingdom, was the natural leader of the queen's party. ${ }^{42}$ There was evidently widespread resentment among some sections of the nobility and the church about the way in which the queen was being treated. I am not convinced by Mayer's argument that Fulk was trying to implement the terms of his marriage settlement and set aside the dying wishes of the old king, since I would suggest that the two settlements did not differ; but whichever interpretation is correct, the consequence was the same: Fulk excluded Melisende from power. ${ }^{43}$ This was not simply a matter of protocol, but also one of patronage: unless the queen had some effective share in the affairs of state she could not reward her supporters with appointments and land. Hugh's revolt failed because he made the tactical error of allying with the saracens, thereby alienating many of his own supporters, but at this point Melisende first

41 Ibid bk 14, caps I 5-18, RHC Occ 1, pp 627-33; on the dating see Mayer, DOP 26, pp 104-6.

12 In C1129 Hugh of Le Puiset witnessed a charter of Baldwin II immediately after the princess Melisende, Kohler, $R O L$ 7, no 21, p 128.

4s Mayer DOP 26, pp 102-13. I can find no evidence to support Mayer's view that Fulk may have wished to repudiate Melisende and set aside the claims of Baldwin III in favour of Elias, the younger son of his first marriage. He seems only to have wished to reduce Melisende to the status of a consort. 


\section{Queens of Jerusalem}

showed her considerable powers of initiative. She rallied her supporters, particularly the churchmen, obtained lenient terms for the rebel count, and, when an attempt was made to infringe this settlement, made life so unpleasant for the king that he was forced to recognise that he could only continue to rule with her co-operation.

The reconciliation of Fulk and Melisende took place before I 136 when their younger son, Amalric, was born. ${ }^{44}$ Thereafter the queen was regularly associated with her husband in official documents relating to the kingdom of Jeruselam. ${ }^{45}$ The scale on which she was able to dispense patronage in those years was expressed in a spectacular way in II38. Of her three sisters, Alice had been married to Bohemond II of Antioch in her father's lifetime, and Hodierna to Raymond II of Tripoli earlier in Fulk's reign, but her youngest sister, Yveta, had become a nun at Saint Anne's. Melisende, who did not consider it fitting that a king's daughter should be a simple choir-sister, founded a convent at Bethany so that when she was old enough her sister could become abbess there. ${ }^{46}$ Recent excavations have revealed the extensive scale of the building operations at Bethany ${ }^{47}$ and the house received endowments commensurate with its status as a royal abbey, including the fertile plain of Jericho. The queen also supplied rich furnishings and liturgical vessels to the house, wishing that it should not be inferior to any community of men or women in the kingdom in wordly wealth. ${ }^{48}$

In the later years of Fulk's life Melisende might justly be described as co-ruler, and from II 38 the child Baldwin III was associated with his parents in some of their acts. ${ }^{49}$ No woman had previously enjoyed such power in the kingdom, but it was to grow greater. In II 43 Fulk

4 Amalric was seven when Fulk died in 1143 , WT bk 15, cap 27, RHC Occ I, p 702,

45 The first of these relates to the gift of Bethgibelin to the Hospital in 1136 . C[artulaire] G[énérale de l'] O[rdre des] H[ospitaliers de St.-Jean de Jérualem (1100-1310). ed J. Delaville Le Roulx], 4 vols (Paris 1894-1906) I, no I16. As Mayer points out, Melisende is not associated with Fulk in documents which he issued as administrator of Antioch, DOP 26, PP I09-10.

4s de Rozière no 33, pp 60-5. Bethany belonged to the canons of the Holy Sepulchre, who were given Thecua in exchange. As Yveta was only about eighteen in $113^{8}$ an elderly abbess was appointed on the understanding that the princess would succeed her.

'T. J. Saller, Excavations at Bethany (1949-1953), Publications of the Studium Biblicum Franciscanum 12 (Jerusalem 1957).

48 WT bk is, cap 26, RHC Occ I, pp 699-700.

49 For example, de Rozière no 32, pp 58-60; [A.] de Marsy, ['Fragment d'un cartulaire de l'Ordre de St.-Lazare en Terre Sainte',] A[rchives de $\left.l^{\prime}\right]$ O[rient] L[atin], 2 vols (Paris 1884) 2, no 2, p 124. 
was killed in a hunting accident: Melisende made the public demonstration of grief which her position as chief mourner required; then she took over the government. Baldwin III was only thirteen, and Melisende is commonly said to have acted as regent for him. This is not what she considered her position to be, nor is it what William of Tyre believed her to have done: he writes, reseditque regni potestas penes dominam Melisendem, Deo amabilem reginam, cui jure hereditario competebat. ${ }^{50}$ Melisende was not a regent, but the queen regnant.

Baldwin III and Melisende were crowned on Christmas day $1143 .{ }^{51}$ The association of the boy Baldwin with his mother shows the strength of feeling in this feudal society that there should be a male head of state, but while Baldwin was under age all power was in the hands of the queen. By reason of her sex she could not command the army, so she appointed Manasses of Hierges, her cousin, who had only recently arrived from the west, as constable of the kingdom, the officer who deputised for the king in military affairs. ${ }^{52}$ In this way she avoided giving too much power to one of her subjects, which might have weakened the royal authority. As co-ruler with a thirteen year old child Melisende had no alternative but to take the measures she did: what surprised her contemporaries was that she showed no signs of relinquishing power to him when he came of age in I145, an occasion which was marked by no public solemnity.

It would be otiose to describe the build-up of tension between Baldwin and Melisende since Mayer has discussed the evidence so thoroughly. ${ }^{53} \mathrm{~A}$ breach had clearly occurred between them by i I so, when Melisende began to issue documents in her own name without reference to Baldwin. ${ }^{54}$ No complaint was made about the quality of the queen's government: she seems to have been a good administrator and to have ruled wisely; but Baldwin and his supporters resented the fact that he had no share in power and was not allowed to make independent decisions. The king blamed the constable Manasses for alienating his mother from him, and matters reached a crisis in II 52

s0 WT bk Is, cap 27, RHC Occ I, p 702 dates Fulk's death I 142, but since he also states that Baldwin III was then thirteen Fulk must have died in I 143. Melisende and Fulk were not married until Pentecost I129 (Whitsun fell on June 2 in that year), so Baldwin cannot have been born before March i1 30 .

51 WT bk 16, cap 3, RHC Oce 1, p 707.

s2 He was in office by 1144 when he led the royal relief force to Edessa, ibid bk 16, cap 4. RHC OCE I, p 710.

${ }^{63}$ Mayer DOP 26, pp $114-66$.

oc de Marsy, $A O L$ 2, no 8, p I29, no IO, pp I30-1; de Rozière no 49, pp 90-2, no 48, pp 87-9. 


\section{Queens of Jerusalem}

when Baldwin demanded to be crowned in the Holy Sepulchre on easter day without his mother's being present. The patriarch Fulcher refused to agree to this, so on easter Monday, 3 I March, the king staged a solemn procession through Jerusalem, wearing a laurel wreath as a symbol of royal power, presumably because the patriarch refused to let him use the crown jewcls. ${ }^{55}$

Baldwin then summoned the high court and demanded that the kingdom should be divided between his mother and himself. The request was criminally irresponsible, for the small kingdom could only maintain its defences satisfactorily if its military resources were under a unified command. Melisende agreed, presumably because she thought that such a solution would be less dangerous to the state than a civil war: she kept Samaria and Judaea while Baldwin held the north. ${ }^{56}$ Melisende has often been criticised for not resigning power gracefully to her son at this time: it is difficult to see what justification she would have felt for doing so; she obviously had the support of the church and of most of the southern lords; she was not a regent clinging tenaciously to power after the heir had reached his majority, but the acknowledged co-ruler of the kingdom; she had governed well, but her son was inexperienced and had shown little capacity for government hitherto. The most important need of the kingdom was to avert a civil war, so she acquiesced in the demands of Baldwin and the northern baronage who supported him.

Mayer is surely right in asserting that this situation lasted only for a few weeks. ${ }^{57}$ The king retired to the north, raised an army and invaded his mother's half of the kingdom. He defeated and deposed the constable, siezed Nablus, and was admitted to Jerusalem by the citizens. Melisende was deserted by many of her vassals, perhaps because the king had now proved himself to be a competent general, which the state needed, and they feared to prolong the civil war in case their enemies took advantage of it. But some of her followers remained loyal to the queen, notably Rohard the Old, castellan of Jerusalem, Philip of Nablus, and her younger son, Amalric, count of Jaffa. The queen and her supporters fortified themselves in the tower of David, to which Baldwin III laid siege. This unedifying spectacle of son fighting mother and brother was brought to an end by the intervention of some unnamed peacemakers, perhaps churchmen. It might have been

${ }^{66}$ WT bk 17, cap 13, RHC Occ 1, p $78 \mathrm{r}$.

so Ibid bk 17, cap 14, RHC Occ I, p 781 .

${ }^{67}$ DOP 16, pp 166-7x. 
expected that Melisende, who had no hope of winning against such unequal odds, would have been allowed to retire with dignity to live with her sister in the convent of Bethany, but she held out for better terms: the city of Nablus and its adjacent lands were granted to her for life and the king swore a solemn oath that he would not disturb her peace. ${ }^{58}$ This shows that although the queen had lost the war she still had powerful allies, for sixteen years of authority had enabled her to exercise a great deal of patronage. The patriarch and the church as a whole took her side and so did her younger son, Amalric, who was now sixteen and heir-presumptive to the throne.

The queen's initiative was not exhausted as she showed soon after this. The king was anxious about the government of north Syria where the power of Nureddin was growing. Antioch was ruled by his cousin Constance, a widow since the death of Raymond of Poitiers in II49, and he wanted her to re-marry in order to provide the state with a new military leader. This need was all the more pressing now that he had sole charge of the kingdom of Jerusalem and could less easily absent himself than he had formerly done to deal with trouble in the north. He therefore summoned a general assembly of the crusader states to meet at Tripoli in the early summer of 1152.59 This was attended by the princess of Antioch and the chief clergy and barons of her state, the high court of Tripoli, and the chief vassals of the king. Queen Melisende also came to Tripoli. The ostensible reason for her visit was to straighten out the marital difficulties of her sister, the countess Hodierna, and Raymond II of Tripoli. It was an astute move, since the queen could not be prevented from paying a visit to her sister, yet when she was there she had to be invited to the assembly since the chief business on the agenda was the marriage of her niece, Constance of Antioch. Neither the assembly nor the royal aunts, Melisende and Hodierna, could persuade Constance to choose a new husband, and Melisende was unsuccessful in

s8 WT bk 17, cap 14, RHC Occ I, Pp $78 \mathrm{I}-3$.

s9 Ibid bk 17, cap 18, RHC Occ I, p 790, places this event after his account of the deposition of Melisende, but gives no date. It is in a section of his work which relates to events in north Syria, some of which occurred before II 52 . Some scholars have therefore placed the assembly of Tripoli before the civil war, for example, [S.] Runciman, [ $A$ History of the Crusades], 3 vols (Cambridge I95I-4) 2, p 333. I accept the date given by Mayer, because the reasons he gives are convincing in the light of a piece of evidence recently discovered, J. Riley-Smith, "The Templars and the Castle of Tortosa in Syria: an unknown document concerning the acquisition of the fortress', EHR 84 (1969) pp 278-88. Mayer's date is also convincing because Baldwin would have been in no position to summon a general assembly unless he had been sole ruler, DOP 26, P 160. 


\section{Queens of Jerusalem}

her attempts to reconcile the count of Tripoli and his wife. Soon after the council the count was nurdered by members of the sect of the assassins, and Hodierna became regent of Tripoli for her young son, Raymond III. After the count's funeral Baldwin III escorted his mother home. By attending the council Melisende had asserted the strength of her influence in north Syria. Henceforth, if the king wished to preserve some measure of control over Tripoli and Antioch, which the rising power of Nureddin and the absence of an adult male ruler in the Christian states of the north made desirable, he would have to treat his mother with outward respect, since the regent of Tripoli was her sister and the regent of Antioch her niecc, and any harsh treatment of Melisende by Baldwin might cause tension between the king and the northern states. ${ }^{60}$

Indeed, as Mayer has shown, the king continued to pay his mother every sign of outward respect. There was a short period of coolness between them, which is scarcely surprising in view of the recent civil war, and during this time the king asserted his sole authority. But once he had established his position as a military leader by conquering Ascalon in II 53 he made peace with his mother. From II 54 onwards she was associated with him in many of his public acts, and he also ratified the grants which she had made by her sole authority during the time of their estrangement. ${ }^{61}$ Melisende's involvement in state affairs after her retirement to Nablus was not always confined to internal matters, such as the transference of land. In I I 6 , for example, the king made peace with the merchants of Pisa concessione Melisendis reginae, matris ... meae. ${ }^{62}$ In I 57 when Baldwin was campaigning in Antioch Melisende took a military initiative. According to William of Tyre, the important cave-fortress of el-Hablis, which controlled the lands of Gilead beyond the Jordan, was recovered from the moslems 'through the planning and zeal of Melisende the queen'. ${ }^{63}$ In the same year the patriarch Fulcher of Jerusalem died, and the appointment of his successor, Amalric of Nesle, was thought to have been due to the intervention of the king's half-sister, Sybil, countess of Flanders, and one of his aunts, perhaps the abbess of Bethany. Again it is significant

๑0 WT bk 17, caps 18, 19, RHC Occ I, pp 789-92.

1 DOP 26, pp I72-5.

-2 Documenti sulle relazioni delle cittì toscane coll'Oriente cristiano e coi Turchi fino all'ammo 1531, ed G. Müller, Documenti degli archivi toscani 3 (Florence I879) no 5 , pp 6-7.

os WT bk I8, cap I9, RHC Occ I, p 8\$I. 
that this important appointment was decided in the circle of the queen, not by the king. ${ }^{64}$

On 30 November I 60 Melisende gave her assent to a gift made by her son Amalric to the Holy Sepulchre. ${ }^{65}$ Soon after this she had what appears to have been a stroke: her memory was impaired and she could take no further part in the affairs of state. Her sisters, the countess of Tripoli and the abbess of Bethany, nursed her for several months. She died on II September II6I and was buried, like her mother, in the shrine of our Lady of Josaphat. ${ }^{66}$ Among her bequests, as befitted the daughter of queen Morphia, she left property to the Orthodox monastery of Saint Saba. ${ }^{67}$

Throughout her life she had been a great benefactor of the church. In addition to founding the convent of Bethany she had also given endowments to the Holy Sepulchre, our Lady of Josaphat, the Templum Domini, the order of the Hospital, the leper hospital of Saint Lazarus, and the Praemonstratensians of Saint Samuel's, Mountjoy ${ }^{68}$ It is not to be wondered at that a good churchman like William of Tyre considered that the eternal salvation of this pious queen was assured. ${ }^{69}$ Her contemporaries do not remark on it, but she was evidently a cultured as well as a devout woman. The psalter which bears her name and which is now in the British Museum is evidence of her interest in the fine arts. Buchtal, who argues that it was executed for the queen in the lifetime of Fulk, has detected the presence of Byzantine, western and south Italian traditions in the illuminations, and concludes: 'Jerusalem during the second quarter of the twelfth century possessed a flourishing and well-established scriptorium which could, without difficulty, undertake a commission for a royal manuscript de grand luxe. ${ }^{70}$ Melisende must be given credit for being an important patron of the artists of the young Latin kingdom.

of Ibid bk 18, cap 20, RHC OCc I, p 854; the king's aunt who is mentioned could also have been Hodierna of Tripoli.

as de Rozière no 58, pp I15-17. Bs WT bk 18, caps 27, 32, RHC Occ I, pp 867, 877.

${ }^{10}$ de Rozière nos 140, 144, pp 256, 262-8.

${ }^{8}$ Holy Sepulchre: de Rozière nos 32, 48, pp 58-60, 87-9; Josaphat: Delaborde, nos 33. 34, 36, pp 80-4; Templum Domini: F. Chalandon, 'Un diplôme inédit d'Amaury I roi de Jérusalem en faveur de l'Abbaye du Temple-Notre-Seigneur', $R O L 8$ (1900-1) pp 311-17; Hospital: CGOH I, nos 175, 191, 244; Saint Lazarus: de Marsy, $A O L$ 2, nos 10, 16, pp I 30-1, 1 35 ; Saint Samuel's: H. E. Mayer, 'Sankt Samuel auf dem Freudenberge und sein besitz nach einem unbekannten diplom König Balduins V', QFIAB 44 (1964) PP 35-71.

- 'Sepulta est autem inclytae recordationis domina Milissendis, angelorum choris inferenda, in valle Josaphat', WT bk 18, cap 32, RHC Occ 1, p 877 .

${ }^{30}$ Buchtal P I4. 


\section{Queens of Jerusalem}

She was a truly remarkable woman who for over thirty years exercised considerable power in a kingdom where there was no previous tradition of any woman holding public office. William of Tyre's comment, that 'she was a very wise woman, fully experienced in almost all spheres of state business, who had completely triumphed over the handicap of her sex so that she could take charge of important affairs', has a patronising ring to a twentieth-century ear. Few, however, would disagree with his judgement that, 'striving to emulate the glory of the best princes ... she ruled the kingdom with such ability that she was rightly considered to have equalled her predecessors in that regard'. ${ }^{71}$

When she died there was already another queen in Jerusalem. In II 57 the high court had debated the king's marriage, and had finally decided to seek a Byzantine bride. It was hoped that Manuel Comnenus would provide a large dowry, and Jerusalem was extremely short of money; but it was also hoped that he might give the crusaders military help against Nureddin. ${ }^{72}$ Baldwin III's envoys were kept waiting in Constantinople for months. The Byzantine emperor was less wealthy than the crusaders supposed: the marriage which they proposed would involve the emperor in great expense and it would be of no value to him unless he could follow it up with a military campaign. In II 57 he could not take his armies to the east because he feared an attack from the Normans of Sicily, but the situation changed in 1158 when the Sicilians made a thirty years truce with Byzantium against their common enemy, Frederick Barbarossa. ${ }^{73}$ Negotiations with Baldwin III's ambassadors then went ahead smoothly. The bride chosen was the emperor's niece Theodora, daughter of the sebastocrator Isaac, who left Constantinople in the late summer of 1 i $58 .^{74}$ The marriage fulfilled all the Franks' hopes: the emperor brought his army to north Syria to fight Nureddin; $7^{75}$ the bride was given a dowry of 100,000 gold hypereroi, a trousseau worth a further 14,000 , and 10,000 hypereroi to defray the expenses of the wedding. There was also the uncovenanted bonus

71 WT bk 16, cap 3, RHC Occ 1, p 707.

"Ibid bk 18, cap 16, RHC Oce 1, p 846.

73 [F.] Chalandon, [Les Comnènes. Etudes sur l'empire byzantin au XIe et XIIe siècle. I. Essai sur le règne d'Alexis Ier Comnène (1081-1118). II. Jean II Comnine (1118-43) et Manuel Ier Comnène (1143-80)] (Paris 1912) 2, Pp 380-1.

74 She reached Tyre in September 1158, WT bk 18, cap 22, RHC Occ I, pp 857-8; Chalandon 2, p 44I.

${ }^{75}$ Gregory the Priest, Continuation of the Chronicle of Matthew of Edessa, cap 123, RHC Arm I, p 186. 
that Theodora, who was twelve, was exceptionally beautiful. The emperor, of course, also madeconditions: the bride should receive as her dowry from Baldwin Acre, the greatest city in the kingdom, to hold for life if she were widowed $7^{76}$ and the king solemnly vowed to secure the recognition of Byzantine overlordship in the principality of Antioch. ${ }^{77}$ On her arrival the queen was taken to Jerusalem where she was solemnly anointed and crowned before being married to the king. Baldwin, whose life-style had previously been a cause of scandal to his more staid subjects, became a reformed character, and the marriage seems to have been a happy one. ${ }^{78}$

The alliance between the crusaders and Byzantium achieved what both sides had hoped it would do: Manuel by a show of military force restrained the aggression of Nureddin, and Antioch acknowledged Byzantine overlordship. Yet although she was so politically important as the chief link in this alliance, Theodora enjoyed no public exercise of power in the crusader kingdom. She was not normally associated with the king in his public acts, and it is arguable that the forceful character of queen Melisende made her sons reluctant to give any share in state affairs to their wives. The two documents in which Theodora is associated with the king are exceptional: one relates to sugar plantations at Acre and was made with the queen's assent presumably because Acre was her dower-fief; ${ }^{79}$ the other was the charter of 31 July 1 I6I in which the king arranged with Philip of Milly to exchange his lands at Nablus for the great fief of Outre-Jordan. This was agreed to by all the members of the royal family, the queen, the king's brother, Amalric, his aunt, Hodierna, countess of Tripoli, and her children, Raymond III and Melisende, which indicates how important the transaction was considered to be. Queen Melisende was dying: her lands at Nablus would revert to the crown, and if the other great landowner there were bought out the whole of Samaria would become part of the royal domain. ${ }^{80}$ Theodora seems to have enjoyed complete freedom in disposing of her

70 WT bk 18, cap 22, RHC Occ I, p 858.

77 This is not recorded by William of Tyre but is in Gregory the Priest, cap I25, RHC Arm I, p I 89.

78 WT bk 18, cap 22, RHC Occ 1, p 858.

$70 \mathrm{~S}$. Pauli, Codice diplomatico del sacro militare ordinte Gerosolimitano, oggi di Malta, 2 vols (Lucca 1733-7) 1, no so, pp so-r.

80 [E.] Strehlke, [Tabulae Ordinis Theutonici] (Berlin r 869) no 3, pp 3-5. Mayer DOP 26, PP 179-80, argues that Baldwin III was punishing Philip for his support of Melisende in II 52. This is not convincing: the fief of Outre-Jordan was greater than Philip's fief at Nablus. The exchange was to Philip's advantage and was only of benefit to the king because he could integrate Philip's lands with his mother's lands. 


\section{Queens of Jerusalem}

own lands: in II6I she granted a house in Acre to her usher, Richard the Englishman, without reference to her husband. ${ }^{81}$

Theodora brought her husband money, prestige, political security and a happy marriage but, perhaps on account of her youth, she bore him no children. When he died on Io February $1163^{82}$ his widow was only seventeen. She retired to Acre and became the first dowager queen of Jerusalem; and for some years she remained the only queen.

Baldwin III was succeeded by his brother Amalric who had in II 57 married his third cousin, Agnes of Courtenay, daughter of Jocelyn II of Edessa. ${ }^{83}$ Agnes was a widow: her first husband, Reynald of Marasch, had been killed in battle alongside Raymond of Antioch in I I 49. ${ }^{84}$ It is not known how old Agnes then was, but since the canonical age of marriage for girls was twelve, she may have been born in 11136 and therefore have been the same age as Amalric. After the loss of western Edessa in I I so she and her mother came to live in Jerusalem, but when Amalric wished to marry her the patriarch Fulcher objected that they were related within the prohibited degrees and the couple seem to have waited to be married until after the patriarch's death in II $57^{85}$ No objection was made by anybody else, including Amalric's mother, the pious queen Melisende. It must have appeared a most suitable marriage; Agnes, it is true, had no dowry, since her family had lost all their lands, but there was no woman of better birth in the kingdom. She bore her husband a daughter, Sibylla, and then, in II6I, a son, the future Baldwin IV, to whom Baldwin III stood godfather. ${ }^{86}$

In I 163 the high court refused to recognise Amalric as king unless his marriage was annulled. It is difficult to establish the true reasons behind this request, which would be unusual in any age, since all three accounts of it are hostile to Agnes: William of Tyre never forgave her for preventing him from becoming patriarch; the thirteenth century Estoire d'Eracles is heavily dependent on William of Tyre for its early

81 de Marsy, $A O L$ 2, no 20, pp $13^{8-9}$. Two Greeks are among the witnesses: Michael Grifo, panetarius, and Dionisius miles, who was presumably a member of Theodora's bodyguard.

62 William of Tyre dates this Io February I 162 , 'regni ejus anno vicesimo . . . aetatis vero tricesimo tertio', bk 18, cap 34, RHC Occ $\mathrm{I}, \mathrm{p} 880$. The twentieth year of Baldwin's reign would not have begun until 25 December 1162 , his thirty-third birthday cannot have been earlier than March I 163 (see note so above). It is therefore generally agreed that he died on 10 February 1163 .

${ }^{88}$ Chronicles of the Reigns of Stephen, Henry II and Richard I, 4, The Chronicle of Robert of Torigni, ed R. Howlett, RS 82, 4 (1889) P I94.

B4 WT bk 17, cap 9, RHC Occ 1, p 775.

${ }^{85}$ Ibid bk 19, cap 4, RHC Occ I, p 889.

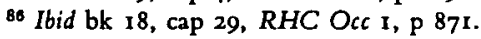


material; while the chronicle of Ernoul was written by a supporter of the Ibelins ${ }^{87}$ who held Agnes responsible for excluding them from the royal succession. William of Tyre and the Eracles give substantially the same account of the annulment: that the patriarch refused to crown the king because his marriage contravened canon law. ${ }^{88}$ William adds that the annulment was made by a papal legate, but that the children of the marriage were declared legitimate. ${ }^{89}$ The chronicle of Ernoul, however, gives what purports to be the objection raised by the lay members of the high court: Car telle n'est que roine doie iestre di si haute cite comme de Jherusalem. ${ }^{90}$ This implies a slight on Agnes's moral character, but this can only be substantiated by instances which this same biased source gives of her lapses from virtue. Although the marriage was annulled on grounds of consanguinity, it is difficult to credit that this was the real reason for objecting to it: the relationship between Agnes and Amalric was such a distant one that William of Tyre, who had been studying overseas when the annulment took place, had to ask the abbess of Sainte Marie-la-Grande to explain the grounds for it to him. ${ }^{91}$ There are two possible reasons why Agnes was unacceptable to the high court: they may have thought that the king could make a more politically and financially advantageous marriage, as he ultimately did; or they may have suspected that Agnes, like queen Melisende, would try to take too active a part in state affairs, as she was later to do.

Agnes kept the title of countess which she had held when Amalric was count of Jaffa and Ascalon. Almost immediately after the annulment she married Hugh of Ramleh, the eldest of the three ambitious Ibelin brothers, a marriage which may, as Ernoul rclates, have been arranged by the king himself: ${ }^{22}$ it certainly relieved him from the duty of making provision for his penniless ex-wife. Although she was never a crowned queen of Jerusalem, Agnes of Courtenay was the wife, mother, mother-in-law and grandmother of kings, and an influential person in the state for twenty years, and must therefore be included in this study.

${ }^{87}$ M. R. Morgan, The Chronicle of Ernoul and the Continuations of Willian of Tyre, Oxford Historical Monographs, (Oxford 1973) pp 41-6.

es [L'Estoire d'] Eracles [Empereur et la Conqueste de la Terre d'Outremer], bk 23, cap 3 RHC Occ 2, p s.

${ }^{80}$ WT bk 19, cap 4, RHC Occ I, p 889.

${ }^{\circ}$ [La Chronique d'] Ernoul [et de Bernard le Trésorier, ed L. de Mas Latrie] (Paris 1871) p 17.

01 WT bk 19, cap 4, RHC Occ I, pp 889-90.

${ }^{2}$ Ernoul p 17; Eracles bk 23, cap 3, RHC Occ 2, p s; WT bk 19, cap 4, RHC Occ 1, p 890. 


\section{Queens of Jerusalem}

It was not until Ir6s that Amalric began negotiations for a second marriage. The chief aim of his foreign policy at that time was to prevent the weakened Fatimid caliphate of Egypt from falling under the control of Nureddin, and to achieve this he needed Byzantine military and financial help. On the advice of the high court he therefore sent an embassy to Constantinople to seek a bride from Manuel Comnenus. ${ }^{93}$ The discussions dragged on for two years because, as Byzantine sources make clear, Amalric wished the emperor to relinquish his claims to sovereignty over Antioch. Amalric eventually gave way about this ${ }^{84}$ and the emperor's great-niece Maria, daughter of the protosebastos John, came to Syria and married the king at Tyre on 29 August $1167 .{ }^{95}$ From the vagueness of Frankish sources it may be inferred that her dowry was not so great as that of her cousin Theodora had been, while the silence even of her supporters about her beauty is equally suggestive.

At the time of Amalric's marriage to Maria the dowager queen Theodora was still living in retirement at Acre. She had not remarried: she could only do so with the king's consent, and Amalric was unlikely to give this, since he would not wish Acre, the greatest city in the kingdom, to pass into other hands, whereas if Theodora remained a widow it would revert to the crown at her death. Her life must have been very boring: she was cut off by background and language from the Frankish nobility among whom she lived, and such ceremonial precedence as she had enjoyed would come to an end with the king's remarriage. In the winter of $1166-7$, when Theodora was twenty-one, there came to the kingdom a distant kinsman of hers, Andronicus Comenus, the emperor Manuel's first cousin. He was an unusual figure in the hieratic court of Byzantium, an adventurer, who would have been temperamentally more at home as a freelance knight in the feudal world of western Europe. His early life had been a series of political and amorous scandals, but in 1166 the emperor had appointed him governor of Cilicia. He soon became bored by his official duties and went to Antioch where he seduced the princess Philippa, a tactless choice, since she was the emperor's sister-in-law, and the resulting scandal was so great that he was forced to leave in haste. ${ }^{96}$ Armed with

\footnotetext{
${ }^{93}$ Ernoul pp 17-18.

Q4 [John] Cinnamus, [Epitome Historiarum], bk 5, cap 13, CHSByz (Bonn 1836) pp 237-8.

os WT bk 20, cap I, RHC Occ 1, pp 942-3; Ernoul p 18.

Do For Andronicus's early life see [C.] Diehl, ['Les romanesques aventures d'Andronic Comnène, Figures byzantines], (5 ed Paris 1918) PP 86-106.
} 
the revenues of Cyprus and Cilicia, which he had had the forethought to collect, ${ }^{97}$ he went to Jerusalem. The king was absent on campaign in Egypt, but, as courtesy demanded, Andronicus called on his kinswoman, the dowager queen. Despite the great disparity in their ages, (Andronicus was in his late forties) Theodora was attracted to him and they became lovers. When Amalric returned from Egypt he was impressed by this distinguished and seemingly rich visitor, who had great charm, and bestowed the fief of Beirut on him. But, in the delightful phrase of William of Tyre, Andronicus behaved to the king 'like a mouse in a wallet' (more muris in pera): for he invited Theodora to visit him in Beirut and, while she was travelling there, abducted her and carried her off to the court of Nureddin at Damascus. ${ }^{98}$

The Franks did not know the reason for this extraordinary behaviour, but an explanation is given by the Byzantine writer, Nicetas Choniates. The emperor Manuel, who had learned of Andronicus's intrigue with Theodora, presumably from one of the noblemen who had escorted queen Maria to Syria, feared that this scandal might jeopardise his carefully constructed Syrian policy. There was no hope of regularising the liaison, for Andronicus had a wife in Constantinople. The emperor therefore sent orders to his agents in Syria to blind Andronicus, which he hoped would satisfy the Franks that he took this slight on the honour of their royal house seriously, but a copy of his letter was seen by Theodora, who informed Andronicus of his danger, and he persuaded her to elope with him. ${ }^{99}$ The defection of a first cousin of the Byzantine emperor and a dowager queen of Jerusalem to moslem Damascus was, as may be imagined, very welcome to the entire islamic world. The couple were received with enthusiasm throughout the moslem near east, and appear to have lived happily together, having two children, a son, Alexis, and a daughter, Irene. Their subsequent adventures are not relevant to this paper, but Theodora, it would seem, died before 1182 when Andronicus made himself Byzantine emperor. ${ }^{100}$ Contrary to Manuel Comnenus's fears the crusader states do not seem to have paid very much attention to this scandal: the Byzantine alliance was assured through Amalric's marriage to Maria, and, as a result of Theodora's elopement, the dower lands of Acre could revert to the crown. ${ }^{101}$

${ }^{97}$ Cinnamus bk 6, cap I, p 250. ${ }^{88}$ WT bk 20, cap 2, RHC Occ I, pp 943-4.

${ }^{90}$ Nicetas Choniates, Historia, De Manuele Comneno, bk 4, cap S, CHSBYz (Bonn 1835) p I 85 .

${ }^{100}$ For Andronicus's subsequent career see Diehl, pp 107-33.

101 Ernoul p Is. 


\section{Queens of Jerusalem}

Maria Comnena took no part in affairs of state during her husband's lifetime. In this regard Amalric followed the example of his elder brother and, like him, had no wish to allow a new queen Melisende to contest his authority. Maria bore the king two daughters, Isabella, who was born in I 172, and another girl who died in infancy. ${ }^{102}$ The lack of a male child was a misfortune not only for the queen, who proved to be a most ambitious woman, but also for the kingdom. For Baldwin, the son of the king's first marriage, had leprosy, and there seems little doubt that had Maria borne the king a son he would have succeeded to the throne. As it was, when Amalric died in I 74 the thirteen year old leper child became king Baldwin IV.

On his deathbed the king granted Maria his mother's former lands of Nablus as a dower fief. ${ }^{103}$ She and her daughter Isabella withdrew from public life, because the unusual situation existed in the new reign that the dowager queen was not the king's mother and had no natural place at court because Baldwin IV's own mother, the countess Agnes, was still living. In I 69 Agnes's third husband, Hugh of Ibelin, had died. ${ }^{104}$ The marriage was childless, and she subsequently married Reynald, son of Gerald, lord of Sidon: William of Tyre places this event in king Amalric's lifetime. A mystery surrounds Agnes's fourth marriage: William of Tyre relates that Gerald of Sidon solemnly swore that the couple were related within the prohibited degrees (he carefully docs not specify how), and that the marriage was consequently annulled. ${ }^{105}$ Gerald may have objected to Agnes on moral grounds as a daughter-in-law since, with or without foundation, rumours were certainly circulating about her indiscretions. ${ }^{106}$ William's account makes it plain that the annulment occurred while Gerald was still alive. This must have been before 1173 , for in that year Reynald first appears in charters as lord of Sidon, which shows that his father had died. ${ }^{107}$ Yet when William of Tyre describes the release of Jocelyn of Courtenay from prison in $1175-6$ he attributes this to the efforts of 'the countess Agnes, wife of Reynald of Sidon'. ${ }^{108}$ Moreover, the list of witnesses to a charter issued in 1179 by Agnes's daughter, Sibylla

${ }^{102}$ Itinerarium [peregrinorum et gesta regis Ricardi I, ed W. Stubbs], bk I, cap 46, Chronicles and Memorials of the reign of Richard I, I, RS 38, I (1864) p 97.

${ }^{103}$ Ernoul p 31 .

${ }^{104}$ Hugh is last mentioned in a document of 1169 (together with Agnes), de Marsy, $A O L$ 2, no 25, pp I42-3.

${ }^{105}$ WT bk 19, cap 4, RHC Occ I, p 890.

100 Ernoul pp 59, 82.

$107 \mathrm{CGOH} \mathrm{I}$, no SSI.

${ }^{108}$ WT bk 21, cap II, RHC Occ 1, p 1023. 
countess of Jaffa, is headed by domina magna comitissa Sagite and dominus Reinaudus Sagite. ${ }^{109}$ Although the lady of Sidon is not given a Christian name in this document it clearly refers to Agnes, for she was the only wife of a lord of Sidon who was entitled to be styled countess: it was, moreover, natural that as Sibylla's mother she should have taken precedence over all the other witnesses. From this it must be concluded that if the annulment was ever granted it was reversed on appeal after Gerald of Sidon's death, and that Agnes remained the wife of Reynald of Sidon probably until her death, but certainly until II79. It is equally clear that William of Tyre did not regard the marriage as valid, and this may account for the disfavour with which Agnes regarded him.

Up to the time of Amalric's death Agnes had little contact with her children: Baldwin IV had grown up at his father's court and Sibylla was brought up in the convent of Bethany by her great-aunt Yveta, queen Melisende's sister. ${ }^{110}$ Nor does Agnes seem to have had any entrée to the court during her son's minority, which ended in 1176 , during which Raymond III of Tripoli was regent. The regent's chief concern was to find a suitable husband for Sibylla, who could take over the government in the event of the king's death or incapacity, since it was evident that, because of his leprosy, the king could not himself marry and beget an heir. The man chosen for the princess was William Longsword of Montferrat, who married Sibylla in the autumn of 1176 and was created count of Jaffa and Ascalon. He died in the following June, leaving his wife pregnant with the future Baldwin V, and countess of Jaffa and Ascalon in her own right. ${ }^{111}$

Agnes seems to have taken no part in the negotiations for the Montferrat marriage, but she was clearly anxious to obtain power at court. Her first step was to arrange for the ransom of her brother, Jocelyn III, titular count of Edessa, who was a prisoner-of-war at Aleppo, for which purpose she raised the considerable sum of 60,000 dinars. ${ }^{12}$ The sick young king came of age in 1176 and Raymond of Tripoli's regency ended, but Baldwin IV had a great shortage of male kin to whom power could be delegated. Jocelyn III was his uncle, and

${ }^{109} \mathrm{~J}$. Delaville Le Roulx, Les archives, le bibliothèque et le trésor de l'Ordre de Saint-Jean de Jérusalem d Malee, BEFAR 32 (1883) no 53, pp 144-5.

110 WT bk 21, cap 2, RHC Occ 1, p 1006.

111 Ibid bk 21, cap 13, RHC Occ 1, pp 1025-6.

112 Ibid bk 21, cap II, RHC Occ I, p 1023; details of the ransom in Chronique de Michel le Syrien, patriarche jacobite d'Antioche (1166-99), bk 20, cap 3, ed with French translation, J. B. Chabot, 4 vols (Paris I899-1924) 3, PP 365-6. 


\section{Queens of Jerusalem}

when he arrived at Jerusalem he was given the important office of seneschal of the realm. ${ }^{113}$

Shortly after William of Montferrat's death count Philip of Flanders, the king's cousin, came to Jerusalem on crusade and claimed the right to arrange marriages for both the king's sisters to his own vassals. The high court refused to agree to this, and Baldwin of Ibelin publicly insulted the count, who was offended and left the kingdom to campaign in Antioch. ${ }^{114}$ Ernoul says that Baldwin acted in this way because he wished to marry Sibylla himself, and this may well be true although Ernoul's chronology is very confused at this point in his narrative. ${ }^{115}$ The Ibelin brothers were certainly very ambitious: in the autumn of I 77 the king gave his consent for the queen dowager, Maria Comnena, to marry the youngest Ibelin brother, Balian, who thus carried on the family tradition of marrying king Amalric's former wives. ${ }^{116}$ By this marriage the Ibelins gained control of the dower-fief of Nablus and custody of the king's younger sister, Isabella. An English source, admittedly one which is very hostile to Maria, gives an unflattering portrait of this marriage: the queen found in Balian, the writer says, ' $a$ husband whose character matched her own ... where he was savage, she was godless; where he was shallow-minded she was fickle; where he was treacherous she was scheming. ${ }^{117}$

The Ibelin marriage excluded the possibility that Maria could, as the king's stepmother, fulfill the duties of queen at Baldwin IV's court. This function was performed by the countess Agnes, whose influence over both her children grew more marked in the following years. When the constable of the kingdom, Humphrey II of Toron, was killed in battle in 1179 Agnes secured the appointment of Amalric of Lusignan as his successor. In Ibelin circles it was rumoured that he was her lover, but, whether this was true or not, he was clearly not chosen simply for that reason, for he was an extremely able man who was later to become an outstanding king both of Jerusalem and Cyprus. ${ }^{118}$ But

\footnotetext{
113 He held that office by I176, CGOH I, no 496; R. L. Nicholson, Joscelyn III and the Fall of the Crusader States (1134-1199) (Leiden 1973) p 73, n 173.

116 WT bk 21, caps 14, I5, 18, RHC Occ 1, Pp 1027-30, 1034-5; Ernoul p 33.

115 Ernoul p 33 places Philip of Flanders's arrival before Sibylla's marriage to William of Montferrat instead of after William's death: this is certainly wrong. He adds that Baldwin had separated from his first wife in order to be free to marry Sibylla, but that when she married William he married the widow of the lord of Caesaraea, pp 47-8. This also is wrong, since Baldwin had married that lady by I175, CGOH I, no 470; Du Cange p $36 \mathrm{~s}$.

116 WT bk 21, cap I8, RHC Occ I, p I035.

117 Itinerarium bk I, cap 63, p 121. 118 Ernoul p 59.
} 
the Ibelins hated Agnes and the Lusignans, whom they held responsible for thwarting Baldwin of Ibelin's plans to become king. It is difficult to establish the truth about this, because the Ibelin assertion rests on the uncorroborated and highly romanticised story told by Ernoul. He relates that Baldwin of Ibelin was captured in battle by Saladin in I I 79 and that while he was a prisoner-of-war the princess Sibylla wrote to him suggesting that he should marry her when he was released. Baldwin was at that time a widower, and therefore free to contract a new marriage, and, as the events of I 77 had showed, he had already aspired to Sibylla's hand. Moreover, Saladin, according to Ernoul, demanded a king's ransom of 200,000 bezants for him, which adds colour to the story. Baldwin was released on security, but since he would have been ruined if he had attempted to pay the ransom. himself, he went to Constantinople to ask the help of the emperor Manuel. It may be supposed that Maria Comnena, who was Baldwin's sister-in-law and the emperor's kinswoman, was behind these negotiations, and that she informed Manuel that Baldwin had every prospect of becoming king of Jerusalem. The emperor, who had always had a strong interest in the crusader states, paid the ransom without raising any difficulty, presumably because he regarded the goodwill of the future king as a sound long-term investment. ${ }^{119}$ The improbable element in this story is the account of Sibylla's indiscretion in writing to Baldwin while he was in prison: possibly Baldwin had previously reached some understanding with her, which was generally known, and which would explain both the size of the ransom which Saladin demanded and Manuel's readiness to pay it.

The wcakness of Ernoul's account is that it treats the whole matter in terms of personal relationships, whereas the marriage of the king's sister and heir was a matter of state. Sibylla was not free to marry whom she chose: the final decision rested with the king and his advisers, and no source suggests that any formal marriage contract had been made between the princess and Baldwin of Ibelin. In fact Baldwin's hopes were frustrated, but for reasons which had nothing to do with Courtenay antipathy towards the Ibelins. The ascendancy of the king's mother and of his uncle, Jocelyn of Courtenay, was challenged by the only other members of the royal house in Syria. The king's health was known to be deteriorating, and at Easter 1 I 80 his cousins, Raymond III of Tripoli and Bohemond III of Antioch, entered the kingdom, it was

119 Maria Comnena's influence is implied by Ernoul who rclates that Manucl offered to pay Baldwin's ransom pour l'amour de Balyan son frere, p 58 . See Ernoul pp $56-60$. 


\section{Queens of Jerusalem}

believed with the intention of choosing a husband for Sibylla, and thus of choosing the next king. Faced by this possible coup d'état the king, acting on his mother's advice, used his prerogative and arranged for Sibylla to be married to the constable's brother, Guy of Lusignan, who had recently arrived from the west. Contemporaries considered that this marriage took place with indecent haste, but it served its purpose by rendering any attempt at intervention by Raymond III and Bohemond III futile. But when, later that year, Baldwin of Ibelin returned from Constantinople, he found that Sibylla was already married. ${ }^{120}$

The Ibelins were angered by this, and do not seem to have considered that if Sibylla had not married Guy she would have been forced to marry somebody other than the absent Baldwin of Ibelin by Raymond III and Bohemond III. Their chief grievance was that they had lost a claim to the throne, and their chances of exercising even indirect power at court became even more remote when the king made formal arrangements for the marriage of his younger sister Isabella, Balian of Ibelin's stepdaughter. She was only eight years old, and therefore below the age for canonical marriage, but a marriage contract was drawn up in October I I 80 between her and Humphrey IV of Toron, stepson of Reynald of Châtillon, lord of Outre-Jordan, who was a firm adherent of the Courtenays and the Lusignans. ${ }^{121}$ Runciman sees in this a conciliatory gesture on the part of the king, intended to heal the division between the Ibelins and the Courtenays, ${ }^{122}$ but it is arguable that it was, on the contrary, designed to deprive the Ibelins of the right to choose a husband for this alternative heir to the throne in the event of the king's death. This marriage too, like that of Sibylla, was almost certainly arranged by Agnes of Courtenay who was the chief immediate beneficiary, for by the terms of the marriage settlement Humphrey surrendered to the king the fiefs of Toron and Chastel-neuf which he had inherited from his grandfather ${ }^{123}$ and Baldwin IV gave them, either then or later, to his mother. ${ }^{124}$ For the first time in her life the king's mother became a great landowner in her own right. William of Tyre's judgement that she was 'a woman who was hateful to God and a shameless money-grabber' therefore seems unduly harsh. ${ }^{125}$

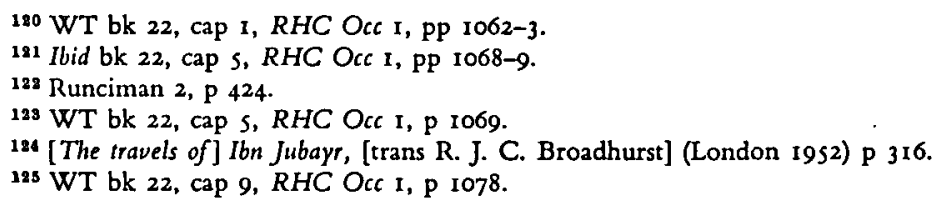


But William had reason to hate her, for when the patriarch Amalric died in October II80 and the canons of the Holy Sepulchre met to choose a successor and submitted two names to the king, Agnes persuaded her son to choose Heraclius, archbishop of Caesaraea, in preference to William of Tyre. ${ }^{126}$ Predictably both Ernoul and the Eracles attribute Heraclius's success to his having slept with Agnes, but since the Eracles places the beginnings of this affair in king Amalric's reign, and attributes Heraclius's first major appointment, that of archdeacon of Jerusalem, to Agnes's favours, the story must be viewed with some mistrust, since the king would surely have been reluctant to bestow office on his former wife's lover. ${ }^{127}$ It is simpler to suppose that Agnes as the king's mother, like queen Melisende before her, was merely exercising rights of church patronage in the patriarchal election, and a reason has already been suggested for her dislike of William of Tyre.

Agnes was clearly a remarkably clever woman. Starting from a position of no power at king Amalric's death, she had secured the appointment of her nominees to the chief lay and ecclesiastical offices in the kingdom by II80: those of seneschal, constable and patriarch; and had arranged the marriages of both the king's sisters to husbands of her own choosing. The territorial power which she and her supporters commanded was equally great: the king held the great cities, Jerusalem, Acre and Tyre; Sibylla and Guy held the counties of Jaffa and Ascalon; Agnes's supporter, Reynald of Châtillon was lord of Outre-Jordan and Hebron; her husband was lord of Sidon; and she held Toron and Chastel-neuf in her own right. Her opponents could not move against her, and when Raymond of Tripoli wished to see the king in I 82 Agnes was powerful enough to refuse to allow him to enter the kingdom. ${ }^{128}$

Her influence was greatest while Baldwin IV was well enough to rule in person, for she was then virtually uncrowned queen. When the king's health grew worse in the summer of 1183 and he appointed Guy of Lusignan as regent Agnes's ascendancy was not threatened, for Sibylla was under her influence and Guy owed his advancement to Agnes. That autumn the princess Isabella, who was now fully of

126 Ibid bk 22, cap 4, RHC Occ I, p I068, reports the election without comment. Full detail in Eracles bk 23, cap 38, RHC Occ 2, pp 58-9; Ernoul pp 82-4.

${ }^{127}$ Eracles bk 23, cap 39, RHC Occ 2, pp 59-60; Ernoul p 82. Heraclius is first nentioned as archdeacon of Jerusalem in a document of 1169 , de Rozière no $167, \mathrm{pp} 30 \mathrm{I}-5$.

128 She later relented under pressure from members of the high court, WT bk 22, cap 9 , RHC Oce 1, pp 1077-9. 


\section{Queens of Jerusalem}

marriageable age, was sent to Kerak of Moab to be married canonically as well as legally to Humphrey of Toron. The festivities were, however, marred by the arrival of Saladin's army, which laid siege to the castle while the wedding-breakfast was in progress. ${ }^{129}$ Baldwin IV meanwhile had been offended by the conduct of Guy of Lusignan as regent and chose the occasion of mustering his host to march to the relief of Kerak to depose Guy from the regency. This was the opportunity for which Agnes's opponents had been waiting, since the king was evidently too ill to live much longer, and as Guy had been excluded the only other serious contender for the regency was Agnes's enemy, the count of Tripoli. With great presence of mind, Agnes advanced a compromise solution which met with general approval. The king should not appoint another regent, but should hold power directly himself: this guaranteed the continuance of Agnes's own ascendancy. But the king should also designate his heir, and exclude Guy of Lusignan from the succession: this conciliated the barons who were hostile to Guy. The heir she suggested was the child Baldwin, whom Sibylla had borne to William of Montferrat: his claim to the throne was impeccable, for he was the king's nephew, but he was also Agnes'sgrandson, and if he becamesole king her position at court would still be assured. The child Baldwin $\mathrm{V}$ was duly crowned and the baronage did homage to him. ${ }^{130}$ As a final act of humiliation to the boy's stepfather, Guy of Lusignan, and as a conciliatory gesture to the Ibelins, which cost nothing, the boy was carried in the coronation procession by Balian of Ibelin, who was the tallest member of the high court. ${ }^{131}$ Only when this was done did the royal army march to the relief of the wedding party at Kerak of Moab. ${ }^{132}$

Agnes's opponents therefore gained no immediate advantage from the disgrace of Guy of Lusignan. The leper king ruled in person for the last years of his reign despite his ill-health; while the Ibelins lost any influence which they may formerly have had over the princess Isabella since Humphry of Toron, acting on his mother's advice, refused to allow his young wife to visit her mother, Maria Comnena. ${ }^{133}$ Agnes

\footnotetext{
129 Ernoul p I03; WT bk 22, cap 28, RHC Occ I, Pp I124-5.

130 WT bk 22, cap 29, RHC Occ 1, pp 1127-8.

${ }^{191}$ Les Gestes des Chiprois, cap 38, RHC Arm 2, p 658, which wrongly date this event I I 8 I.

132 I propose to publish elsewhere my reasons for supposing that the relief of Kerak was delayed by the deposition of Guy de Lusignan. It is implicit in William of Tyre's account, bk 22, caps 28-30, RHC Occ 1, pp 1124-30.

${ }^{139}$ Eracles bk 25, cap 11, RHC Occ 2, p is2.
} 
could not prevent the king from pursuing his vendetta against Guy: he sought, with the help of the patriarch, to have Sibylla's marriage annulled, but Guy and Sibylla foiled this attempt by shutting themselves in Ascalon and refusing to leave even when the king summoned them in person. Since proceedings in a matrimonial case could not be heard in the absence of the contracting parties the case was abandoned. ${ }^{134}$ This happened in the early months of 1184 . The countess Agnes did not intervene, although she was still alive then, for when Ibn Jubayr, secretary of the moorish governor of Granada, passed near Toron in September of that year he remarked with the tolerant courtesy which characterises moslem writings about Christians in that period: Toron 'belongs to the sow known as queen who is the mother of the pig who is lord of Acre-may God destroy it.' ${ }^{135}$

It is not known whether Agnes was still alive when Baldwin IV died in II85 and Baldwin V became sole king under the regency of her chief enemy, Raymond of Tripoli. If she was, her influence, although diminished, would not have been at an end, since her brother Jocelyn was the personal guardian of the young king. Her death occurred before the late summer of 1186 , for she took no part in the succession crisis which arose then, and on 2I October king Guy acknowledged that count Jocelyn, who was her executor, had satisfactorily discharged the provisions of her will. ${ }^{136}$ Agnes was, in many ways, a worthy daughter-in-law of queen Melisende. She lacked, it would seem, her mother-in-law's piety, but she shared her desire for political power and had a more decisive influence on the history of the first kingdom than any other woman except Melisende herself. It was her misfortune to have bad relations with the press: all contemporary sources are hostile to her, but they are not unprejudiced and it is arguable that her influence was not as baneful as the Ibelins and the archbishop of Tyre would like posterity to suppose.

Any hope that the coronation of Baldwin $\mathrm{V}$ would resolve the tensions of the kingdom was rendered ineffectual by the young king's death in the late summer of I186. Raymond of Tripoli had only consented to be regent on the understanding that should Baldwin $V$ die a minor the chief rulers of the west should be asked to adjudicate between the claims of his two sisters to the succession. ${ }^{137}$ Accordingly

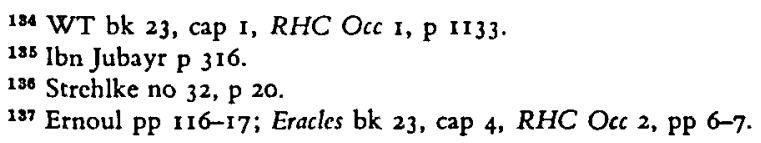




\section{Queens of Jerusalem}

when Baldwin V died Raymond summoned the high court to Nablus to discuss the succession, while Jocelyn of Courtenay, as the dead king's guardian, made arrangements for his burial in Jerusalem. Guy and Sibylla attended the funeral with a strong armed escort with which they garrisoned the city. It is too well-known to need repeating here, how Sibylla, with the help of her supporters, who were, for the most part, the old supporters of Agnes of Courtenay, stole a march on the high court of Nablus and was crowned queen. Two points are worth emphasising: first Reynald of Châtillon gained popular support for Sibylla by affirming that she was li plus apareissanz et li plus dreis heirs dou roiaume; secondly that the patriarch crowned Sibylla alone, and that she conferred the crown on Guy. There was no real doubt, following the precedent of Melisende, that Sibylla, as the elder daughter of king Amalric, had the best claim to the throne; equally, there could be no doubt after the ceremony that Guy only held the crown matrimonial. ${ }^{138}$

Humphrey of Toron and the princess Isabella were present at Nablus, and when news reached the high court there of the coronation of Sibylla and Guy the barons wished to crown Humphrey and Isabella in opposition to them. Humphrey wrecked this plan by going to Jerusalem and taking the oath of fealty to Sibylla: he had never liked the Ibelins and, it may be argued, had no wish, in the event of a civil war, to fight against his mother and stepfather, both of whom supported Guy. Once they were deprived of an alternative candidate most of the barons at Nablus made their submission to Sibylla and Guy. ${ }^{139}$ But Maria Comnena never forgave her son-in-law for depriving her daughter of the chance to be queen, a chance which would have led to the restoration of Maria herself to a position of power. ${ }^{140}$

Had Sibylla lived in more peaceful times she could have exercised a great deal of power since her husband's authority so patently derived from her. In the first few months of the reign, indeed, she was associated with Guy in some of his acts. ${ }^{141}$ But the conquest of Saladin, which occurred within a year of the coronation, brought Guy and Sibylla's joint rule to a speedy end. When Guy was taken prisoner at Hattin, Sibylla was in Jerusalem, where she was joined by her stepmother,

\footnotetext{
${ }^{198}$ Ernoul pp r30-4; Eracles bk 23, cap 17, RHC OCc 2, pp 26-9.

${ }^{130}$ Eracles bk 23, caps 18-21, RHC Oce 2, pp 30-3; Ernoul pp 134-9.

140 Eracles bk 25, cap I1, RHC Occ 2, p I52.

141 Strehike nos 20, 21, pp I8-19.
} 
Maria Comnena. Both ladies were treated courteously by Saladin: Sibylla was allowed to join her husband, who was in detention at Nablus, ${ }^{142}$ and Maria Comnena and her children were allowed to go to Tripoli, despite the fact that Balian of Ibelin failed to keep the oath which he had sworn to the sultan not to take up arms against him when Saladin gave him permission to go to Jerusalem to escort his wife to safety. ${ }^{143}$ After Jerusalem had fallen Guy was taken to Damascus, but Sibylla was allowed to join queen Maria in Tripoli.

She stayed there until she was joined by Guy on his release from captivity in I $188 .{ }^{144}$ The only city in the kingdom of Jerusalem which remained in Christian hands was Tyre, but when Guy and Sibylla marched there in 1189 they were refused entrance by Conrad of Montferrat, who had taken charge of its defence. After some months spent outside the walls, Guy led the vanguard of the third crusade, newly arrived in Syria, to lay siege to Acre, ${ }^{145}$ and among those who followed him there were Humphrey of Toron and the princess Isabella, and Balian of Ibelin and Maria Comnena. It seemed as though former differences had vanished in the face of a common disaster. How illusory this unity was became apparent when Sibylla died of an epidemic in the camp at Acre on 25 July I190, together with her two little daughters, Alice and Maria. ${ }^{146}$

Guy's enemies, and there were many who blamed him for the defeat of Hattin, claimed that as he only had the crown matrimonial his kingship ended with the death of his wife. The only other candidate for the throne was the princess Isabella, but her husband Humphrey was a friend of Guy's and unwilling to set himself up as king in opposition to him. Conrad of Montferrat, hero of the defence of Tyre, was an ambitious man who wanted to become king, and who found a ready ally in Maria Comnena. She deposed before the archbishop of Pisa, the pope's legate, and the bishop of Beauvais, that her daughter's marriage was invalid because she had only been eight when it was contracted, and had been forced into it by Baldwin IV against her wishes. Isabella, who was happily married and had no wish to be separated from her husband, was browbeaten into agreeing with this

\footnotetext{
162 Ernoul p 185.

142 Ibid pp 186-7; Eracles bk 23, cap 46, RHC Occ 2, pp 68-71.

144 Ernoul p 252; Eracles bk 24, cap II, RHC Occ 2, pp 120-I.

145 Eracles bk 24, caps 13, 14, RHC OCc 2, Pp 123-5; Ernoul pp 256-7.

140 Sibylla had borne Guy four daughters. It is not clear whether they all died at the same time as their mother or whether two had predeceased her: Ernoul p 267; Eracles bk 25, cap I0, and see also variant readings $C$ and $G, R H C$ Occ 2, PP ISI, 154.
} 


\section{Queens of Jerusalem}

statement by her strong-willed mother. The legate annulled the marriage; Isabella was then crowned, and immediately restored to Humphrey his fiefs of Toron and Chaste-neuf (an academic piece of justice since they were in enemy occupied territory); then she was married to Conrad. ${ }^{147}$ Maria Comnena had had to wait for sixteen years to see her daughter made queen, but her patience was finally rewarded. As her conduct in the matter of the annulment shows, there was some truth in her opponents' view that she was a ruthless and scheming woman. 148

Maria bore Balian of Ibelin four children: John, who became the 'old lord' of Beirut; Philip of Ibelin, who later became bailli of Cyprus; Margaret, who married successively Hugh of Tiberias, and Walter III of Caesaraea; and Helvis, who, ironically, married Reynald of Sidon, former husband of the queen's old rival, Agnes of Courtenay. When Balian died in about $1194^{149}$ Maria did not remarry. She continued to take an active part in forwarding the interests of her family: in 1208 she helped to arrange the marriage of her grand-daughter Alice to king Hugh I of Cyprus. ${ }^{150}$ She apparently died in the summer of 1217 , for in October of that year Hugh I of Cyprus confirmed the endowment made by her son, Philip of Ibelin, for masses to be said in Nicosia cathedral for the repose of the soul of his mother inclite recordationis. ${ }^{151}$ She had lived to see her great-grand-daughter, Isabella II, become queen of Jerusalem, and all the kings of Jerusalem and Cyprus, together with many of the higher nobility in both states in the thirteenth century, were descended from her. ${ }^{152}$ By the time of her death she was the sole survivor of any consequence from the first kingdom of Jerusalem. She had occupied a central position in the state for twenty yeurs before its fall. Perhaps the reputation which her son, the 'old lord' of Beirut, acquired as a repository of knowledge about the laws and customs of the first kingdom owed much to the memory of his long-lived mother.

147 Eracles bk 25, caps I1, 12, RHC Occ 2, pP I 51-4; Itinerarium bk I, cap 63, Pp 119-22: Ernoul pp 267-8 does not mention Maria's involvement.

148 See note ins above.

$160 \mathrm{He}$ is last recorded in a document of that year, CGOH I, no 954 .

180 Alice was the daughter of Maria's eldest child, queen Isabella, by her marriage to count Henry of Troyes. G. Hill, $A$ History of Cyprus, 4 vols (Cambridge 1940-\$2). 2, P 75 .

${ }^{161} \mathrm{~L}$. de Mas Latrie, Histoire de l'lle de Chypre sous le règne des princes de la Maison de Lusignan, 3 vols (Paris I8s2-61) 3. pp 608-9.

152 See the genealogical table at the end of Runciman 3. 


\section{BERNARD HAMILTON}

Maria Comnena had great resilience and considerable powers of adaptation. She became queen of Jerusalem because that state needed the alliance of the powerful Byzantine empire. After I 180 Byzantium had ceased to be a world power, and before her death it had almost ceased to exist at all as a result of the fourth crusade. The kingdom of Jerusalem likewise had dwindled into the kingdom of Acre, yet Maria's influence increased rather than diminished under these adverse conditions. Like Agnes of Courtenay and queen Melisende, Maria Comnena had a central interest in power, though she was more concerned with the realities and less with the external trappings of power than they had been, and in consequence was more devious in her methods of attaining it.

All eight queens who reigned in the first kingdom made a serious impact on its development: this is true even of those of them who were a-political, like Theodora, whose dowry strengthened the inadequate finances of the state, and who was the personal link by which the Byzantine alliance was forged, which held the threat of Nureddin in check. Further investigation would probably show that women were equally influential at other social levels in this outwardly maledominated feudal state.

University of Nottingham 